\title{
Accounting treatment analysis of rahn tasjily financing
}

\section{Suhadak}

Universitas Islam Negeri Maulana Malik Ibrahim Malang, Indonesia email: suhadak328@gmail.com

\begin{abstract}
Purpose - The purpose of this study was to describe the accounting treatment of rahn tasjily financing transactions carried out by BMT UGT Sidogiri Malang with PSAK 107 and the suitability of the transaction application with Fatwa DSN MUI DSN No.68/DSN-MUI/III/2008.

Method - This study used descriptive qualitative method.

Result - The research shows that the recognition and measurement of Ijarah transactions are in accordance with PSAK 107, but the presentation and disclosure are not appropriate. Recognition, measurement, and presentation of rahn tasjily financing transactions are in accordance with PAPSI, but the disclosure is not yet appropriate, and accordance with the application of Fatwa DSN MUI DSN No.68/DSN-MUI/III/2008.

Implication - This study has an impact on the compliance of the institution in carrying out rahn tasjily financing of PSAK and Fatwa DSN MUI DSN No.68/DSN-MUI/III/2008.

Originality - The focus of this study is the application of the determination and accounting treatment of ljarah costs in rahn gold according to PSAK 107 and Fatwa DSN MUI DSN No.68/DSN-MUI/III/2008.
\end{abstract}

Keywords: $\quad$ rahn tasjily; PSAK 107; PAPSI VII; fatwa DSN MUI No. 68/DSN-MUI/III/2008 
Suhadak

\section{Introduction}

BMT UGT Sidogiri is one of the sharia financial services cooperatives that has good development, as evidenced in 2014 the number of service units was

JIAFR | 120258 units and by the end of 2015 it had grown to 273 units consisting of main branches and auxiliary branches spread across most parts of Indonesia (RAT BMT UGT Sidogiri, 2015). BMT UGT Sidogiri has good experienced on asset growth, in October 2016, in October 2016 the number of assets reached IDR2.2 trillion, so that the percentage obtained per October with the base year of 2014, in 2015 increased by $34.80 \%$ and in 2016 amounted to $68.60 \%$ (Bakhri, 2016).

The increase in assets had a positive impact on increasing members which reached 12,901 members at the end of 2015 from a total of 11,602 members in 2014 (RAT BMT UGT Sidogiri, 2015) . This was supported by products offered by BMT including rahn tasjily financing products. The product is financing disbursed with a service contract with total financing of Rp.280,943,518,750, the number occupies the second number after financing based on the murabahah contract of Rp.713,861,164,076 (RAT BMT UGT Sidogiri, 2015), the financing products rahn tasjily is one of the superior products owned by BMT UGT Sidogiri.

The implementation of Rahn tasjily financing at BMT UGT Sidogiri, Malang, is a financing member who guarantees his goods accompanied by limited proof of ownership for immovable property such as land, houses, etc. On the other hand, the property remains with the power of the person who guarantees it (rahin) and the BMT (murtahin) only accepts proof of ownership and provides loans for a number of funds, then the BMT promises to maintain proof of ownership of assets that are secured in a certain period of time agreed upon by members and BMT. This financing transaction is based on general rules contained in the Quran QS. Al-Baqarah verse 283.

Rahn tasjily financing transactions also require an accounting framework that is integrated other accounting transactions that can produce appropriate accounting treatment. As the opinion of Mardiasmo (2004) as follows: "The 
obligation of the trustee to provide accountability, present, report, and disclose all activities and activities that are his responsibility to the trustee who has the right and authority to hold such responsibility". The statement indicates the importance of accounting communicating information appropriately with quality that can be relied on by users of information JIAFR | 121 according to the right standards.

Based on the increase in members who use rahn tasjily financing and the importance of communicating accounting information according to appropriate standards, supervision of the financing practices is needed, one of the accounting treatment and conformity with fatwa DSN. It is the products in accounting activities (accounting treatment) have not yet had accounting standards specifically regulating guidelines in carrying out their accounting treatment, as an alternative measure of customary accounting standards generally accepted as a guideline in carrying out accounting treatment activities.

PAPSI section VII concerning qardh loan agreements as a guide to accounting treatment in qardh transactions (BI, 2013) and PSAK 107 concerning Ijarah accounting is a guideline in the accounting treatment related to Ijarah transactions (IAI, 2009) as a mix of guidelines for accounting treatment, and Fatwa DSN MUI No. 68/DSN-MUI/III/2008 concerning rahn tasjily as a reference in conducting the rahn tasjily financing transaction (DSNMUI, 2014).

The research objective to be achieved in this study was to find out the accounting treatment of rahn tasjily financing at BMT UGT Sidogiri, Malang based on PAPSI section VII on qardh loan agreements and PSAK 107 concerning Ijarah accounting, and to know the suitability of rahn tasjily financing at BMT UGT Sidogiri Branch Malang City based on Fatwa DSN MUI No. 68/DSN-MUI/III/2008 concerning rahn tasjily. 
Suhadak

\section{Literature Review}

In general, the understanding of rahn tasjily refers to the basic contract of the rahn contract. According to language, pawn ( $r a h n)$ means al-tsubut and al-habs namely determination and detention (Suhendi, 2013). There is also an explanation, the rahn is confined or entangled (Sahrani and Abdullah, 2011). While the term/terminology, according to Sayyid Sabiq, rahn is making goods that have property values according to Islamic teachings as collateral for debt, so that the person concerned can take the receivables or take part of the benefits of the goods (Wangsawidjaja, 2012). Pawn (rahn) can also be interpreted as an item that is used as reinforcement or reinforcement of trust in accounts payable (Suhendi, 2010).

The understanding of pawn (rahn) according to Sutedi (2011) is a muamalah system where one party provides a loan and one saves valuable or valuable goods as collateral for a loan to a person who receives a mortgage, explicitly rahn is giving an item to be held or be used as collateral/handle when the borrower's fault is unable to repay the loan in accordance with the agreed time and also as a binder of trust between the two, so that the lender does not doubt the return of goods borrowed.

The above definition is the meaning of rahn in general. Whereas the understanding of tasjily is collateral in the form of goods for debt but the collateral (marhun) remains in the possession (utilization) of rahin and the proof of ownership is left to murtahin (DSN-MUI, 2014).

Rahn tasjily legal basis refers to the Quran which became the first reference as the basis of the rules of Islam in the world, in the Quran AlBaqarah (2): 283 is the basis relating to the Islamic pawn contract (rahn).

"And if you are on the way while you are not getting a writer, then there must be a guarantee item held. But, if some of you are believing in others, let the one who believes trusts his debt (debt) and let him fear Allah, his Lord. And do not hide the testimony, because whoever conceals it, really, his heart is dirty (sinful). Allah is Aware of what you do". (QS. Al-Baqarah: 283)

By looking at the letter Al-Baqarah verse 283 it can be said that muamalah is not in cash when safar and there is no author to write the 
transaction then rahn in that condition is sunnah. In the condition of the legal mukim mubah (Sutedi, 2011).

Shaykh Muhammad Ali As-Sayis argues, that the verses of the Quran above are instructions for applying the precautionary principle if someone wants to conduct debt transactions that use a period of time with others, by pledging an item to the person who debt ( $r a h n)$ (Ali, 2008).

Shaykh Muhammad 'Ali As-Sayis also revealed that rahn can be done when two parties transacting are traveling, and such transactions must be recorded in an official report (someone wrote it down) and someone who witnesses it. Even 'Ali As-Sayis considers that with rahn, the principle of prudence is actually more secure than written evidence coupled with someone's testimony. Even, the recipient of the mortgage (murtahin) is also permitted not to receive collateral (marhun) from the pawn giver (rahin), on the grounds that he believes the pawnshop (rahin) will not avoid his obligations. Because, the substance in the rahn event is to avoid harm caused by the betrayal of one of the parties or both parties when both conduct debt transactions (Ali, 2008).

The rahn tasjily practice in Islamic financial institutions has a basic contract. Such contracts such as qardh, according to Nawawi (2012) qardh is to hand over money to people who can use it then he asks for a refund of a certain amount of money. Another definition of qardh is to give property to people who will use it and return it in the future (Mardani, 2012).

Another contract which is the basis of the practice of rahn tasjily is the Ijarah contract, which according to hanafiyah argues that Ijarah is a contract or a benefit with a substitute, while the Syafi'iyah argue that Ijarah is a contract for a certain purpose and change, and accepts substitutes or permits with certain substitutes, while the Malikiyyah and Hanabilah scholars declare that Ijarah is to make property a modified benefit in a certain time with a substitute (Syafi'i, 2001).

The rahn tasjily contract is practiced in the Baitul Mal wat Tamwil (BMT), where BMT itself consists of two terms, namely baitul mal and baitut tamwil. 
Baitul Mal refers to efforts to collect and channel and non-profit, such as: zakat, infaq and sadaqoh. While baitut tamwil as a business of collecting and distributing commercial funds. These efforts become an inseparable part of BMT as an institution supporting economic activities of small communities based on sharia (Sudarsono, 2007). The activity of rahn tasjily contract in BMT is called financing.

Based on Law No. 10 of 1998 concerning banking Chapter 1 article 1 No. 12 that the financing based on sharia principles is the provision of money or bills that can be equated based on an agreement between the bank and other parties which requires the finance party to return the money or bills after a certain period of time with compensation or profit sharing in accordance with the agreement.

The operational principle of BMT is based on productive financing patterns, both those that are intended as working capital and investment, the community can choose four BMT financing models. The pattern of BMT financing in general Sumiyanto (2008) classifies BMT financing into four general categories, namely: First, the principle of profit sharing (syirkah) is a form of financing to members who include a number of capital both cash and goods to increase productivity. The financing system is applied in two financing agreements, namely mudharabah financing and musyarakah financing (Ridwan, 2004), where from the financing will result in profits and losses that will become a benchmark in the profit sharing system, both profit and loss in accordance with the contract provisions.

Second, the principle of buying and selling is a procedure for buying and selling, the implementation of which BMT appoints members as agents authorized to purchase goods in the name of BMT, and then acts as a seller, by selling the purchased items with a plus mark-up. The benefits of BMT will be shared with fund providers, examples of the principle of buying and selling are bai 'al-murabahah, bai' as-salam, bai 'al-istishna', bai 'bistaman ajil, etc. (Ali, 2008). 
Third, the principle of leasing is financing aimed at obtaining services, where the profits ahead and become part of the price of goods or goods rented, which fall into this category are ijarah and Ijarah Muntahia Bit Tamlik (IMBT) (Rianto, 2010).

Fourth, the principle of service is a form of financing that is basically ta'awuni or help, various developments in this contract include: wakalah, kafalah, hawalah and rahn (Sumiyanto, 2008).

The application of rahn tasjily contract to BMT is explained through the rahn scheme in general, following the scheme of rahn (Antonio, 2001).

The scheme above explains that rahin (member) has a marhun (guarantee) that will be deposited as a financing basis for a pawn contract (rahn), then from the ownership of marhun (collateral) from rahin (member), rahin proposes a number of financing (marhun bih). The BMT and members agree on the amount of financing, then the two parties make a contract based on the sharia contract, rahn. Finally, there was a handover of a number of debts (financing) and the BMT determined ijarah fees for the maintenance and maintenance of marhun.

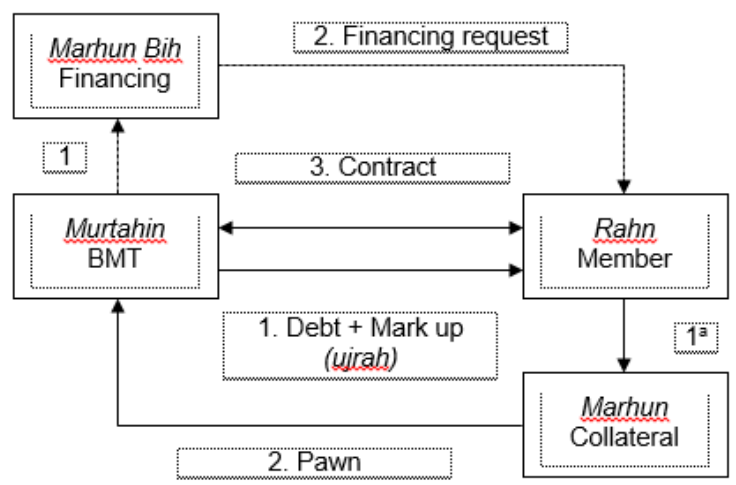

Figure 1. Rahn Scheme 
Suhadak

Explanation of the scheme of the picture above has similarities with the financing of the rahn tasjily contract carried out by BMT, but from the rahn tasjily contract, marhun remains in the possession of rahin, and murtahin only accepts proof of ownership from the marhun. From the receipt of proof of ownership from the marhun by BMT, the BMT determines a number of ijarah fees for the safeguards it does.

Sharia Enterprise Theory is the initial of trust metaphor as a figure of speech to see, understand and develop business has been expressed in order to look for a more humanist, emancipatory, transcendental and teleological organization. This metaphor has fundamental implications for the concepts of management and accounting (Triyuwono, 2006)

According to Triyuwono, Sharia Enterprise Theory is that God as the Creator and Sole Owner of all the resources in this world, God as the main source of trust and resources possessed by stakeholders, is inherent in the resources of responsibility in use, manner and purpose determined by the Trustee. The mandate form of Islamic accounting embodies accountability (Mulawarwan, 2009).

Several studies have been conducted in the field of sharia accounting both at the conceptual and practical level. One view was conveyed by Adnan and Triyuwono, who essentially recommended enterprise theory as a theoretical concept of Islamic accounting. Implicitly, Triyuwono expressed:

"Islamic accounting is not only a form of accountability in management of the owner of the company (stockholders) but also as accountability to stakeholders and God". (Triyuwono, 2000)

Referring to these opinions, theoretical concepts that are able to provide the basis for the formation of accounting principles and activities that produce accountability and the exact information needed by information users is Enterprise Theory. 
These theoretical concepts are based on important implications contained in the Quran surah al-Baqarah: 254 and 267, an-Nur: 56, alBaqarah: 215 and al-Baqarah: 273. The concepts include the concepts of zakat, justice, maslahah, responsibility and falah in accordance with the characteristics of sharia accounting formulated by Triyuwono (Triyuwono, 2000).

Rahn tasjily financing related to accounting still refers to generally accepted custom accounting standards, including Sharia Charges Accounting Guidelines (PAPSI) section VII concerning qardh accounts given and PSAK 107 concerning ijarah accounting as a basis for accounting treatment, and Fatwa DSN MUI No. 68/DSN-MUI/III/2008 concerning rahn tasjily which regulates its suitability with sharia principles.

PAPSI part VII Contract of Qardh loan that is given is the provision of funds or bills that can be equalized based on an agreement between the borrower and the lending party that requires the borrower to repay the debt after a certain period of time (BI, 2013). The accounting treatment is based on PAPSI VII, namely: 1) Recognition and measurement, states that qardh loans are recognized at the amount loaned at the time of occurrence. 2) Presentation, stating that qordh originating from third parties is presented on the qordh loan post. 3) Disclosure, states that things that must be disclosed, among others: a) details of the amount of qardh loans based on the source of funds, type of use and economic sector, b) the number of qardh loans given to related parties, c) management policies in implementation qardh loan risk control.

PSAK 107 is applied to the accounting treatment of entities carrying out ijarah transactions. PSAK 107 also includes arrangements for financing using the rahn tasjily contract, because there is an Ijarah contract from a separate transaction with the financing that uses the contract, except for the treatment of the accounting treatment for Islamic bonds using the Ijarah contract. Rahn tasjily adapts to the fatwa that regulates it, namely No. 68/DSN-MUI/III/2008 concerning rahn tasjily which regulates several provisions relating to the Ijarah contract (DSN-MUI, 2014), namely: 1) Murtahin can charge 
maintenance and storage fees for marhun goods (in the form of legal proof of ownership or certificate) borne by rahin. 2) The amount of maintenance and storage costs for marhun goods must not be related to the number of loans given. 3) The amount of fees as referred to is based on real expenses and other expenses based on the Ijarah agreement.

\section{Research Methods}

This research belongs to the category of qualitative research with a descriptive analysis approach. According to Moleong (2014), qualitative research is research that intends to understand the phenomenon of what is experienced by research subjects such as behavior, perceptions, motivations, actions etc., holistically, and with a specific natural context and by utilizing various methods natural. Research decrypts accounting treatment including acknowledgment, measurement, presentation, and disclosure of rahn tasjily financing and analyzes its suitability with PAPSI part VII about qardh loan given and PSAK 107 concerning Ijarah accounting as companion contract, and analyzes conformity with Fatwa DSN MUI No. 68/DSN-MUI/III/2008 about rahn tasjily at BMT UGT Sidogiri Malang City Branch.

The research location at BMT UGT (Baitul Mal wat Tamwil Integrated Joint Business Regional Office) Sidogiri Malang is addressed at Jl. Kebalen Wetan No. 01 B RT/RW. 04/01 Kedung Kandang Malang. The research subjects were Mr. Achmad Junaidi Nur as head of the branch of BMT UGT Sidogiri Malang and Mr. Zainullah as Head of Financing Account Officer. The type of data needed is qualitative and quantitative data. The data source consists of primary and secondary. While the data collection techniques are interviews and documentation. The analysis of the data used is using the techniques proposed by Miles and Huberman, covering three types of activities, namely: 1) Data reduction, 2) Data model (Data display), and 3) Conclusions and verification conclusions (Emzir, 2010). 
Accounting treatment analysis of ...

\section{Results and Discussion}

The implementation of rahn tasjily financing conducted by BMT UGT Sidogiri Malang to members is a transaction that will lead to an accounting activity, where there is recognition, measurement, presentation and disclosure (accounting treatment) of the financing activity. In financing rahn JIAFR | 129 tasjily in practice, members continue to control their security goods and the BMT only accepts securities, because the financing is based on guarantees that do not move, such as land.

Guarantees held by members and remain in their possession, members only surrender securities on their possessions to obtain the required number of loans, the BMT has the maximum amount of the loan amounting to Rp. 25,000,000.00 (twenty-five million rupiahs) for financing at the branch level (Results of Interview with Mr. Junaidi Nur, Branch Head) on February 28 at 10:20 WIB, because the target of financing in BMT is micro.

BMT UGT Sidogiri Malang in its accounting practice uses computerization, where every transaction, especially financing rahn tasjily is automatically inputted to the computer. The explanation is based on the results of interviews with Mr. Junaidi Nur (Branch Manager) dated February 28, 2017 at 11.20 WIB, namely:

"For accounting at BMT UGT, Sidogiri is already using a computer, so we just have to get the results from the transactions here (BMT UGT Sidogiri, Malang city branch)".

On the other hand, in accounting treatment (recognition, measurement, presentation, and sufficiency) BMT Sidogiri Malang city branch has its own guidelines. BMT UGT Sidogiri Malang in the accounting treatment of rahn tasjiy financing transactions, including recognition and measurement. When the handover of the land certificate is not recognized by the BMT, it is based on the results of an interview with Mr. Junaidi Nur (Branch Manager) on February 28 at 13.08 WIB, stating that:

"We only hand over (land certificate), with a signature from BMT and members". 
Suhadak

Recognition and Measurement at the time of Disbursement. BMT UGT Sidogiri Malang recognizes rahn tasjily financing at the time of disbursement given to members of a number of loans (cash) that have been agreed upon as loan service contracts in accordance with the value/amount submitted to members at the time of submission, for example as much as Rp. $15,000,000.00$ submitted to the following members of the journal:

Rahn tasjily financing disbursement journal:

Dr. Loan service contract of Rp. 15,000,000.00

Cr. Cash Rp. 15,000,000.00

Recognition and Measurement when BMT receives an installment from a member, by BMT is recognized as a deduction of service contract loan every time the member pays the installment, and at the time BMT receives ujrah on the care of the land certificates belonging to the owner over the financing of rahn tasjily. BMT acknowledges at the time the care service has been made in accordance with the acceptance of ujrah (care costs) of the member of the service provided as a service fee Ujrah. the following installment calculations payable by the members are as follows: 1) Ujrah requested by the BMT UGT Sidogiri branch of Malang city for the first month is Rp.390.000,00 (three hundred and ninety thousand rupiah), the calculation from:

Ujrah = Plafond Financing $x$ Ujrah Rate

Ujrah $=$ Rp. $15.000 .000,00 \times 2.6 \%$

Ujrah $=$ Rp. 390.000,00

The ujrah tariff is $2.6 \%$, due to the long-term financing of 24 (twenty four) months or over 1 (one) year. 2) Principal Loan Installment is generated from the large loan divided by long loan, namely:

Principal loan installment $=R p .15 .000 .000,00 / 24$ months

Principal loan installment $=R p .625 .000,00$

From the above calculation it can be used as a registering guide by BMT UGT Sidogiri Branch Malang city for the first month of installment, as follows: 
Accounting treatment analysis of ...

Dr. Cash Rp. 1.015.000,00

Cr. Service Charge Loan Rp. 625.000,00

Cr. Ujrah Akad Service Rp. 390.000,00

Once the members pay the installment until paid, the BMT makes a letter of handover of the land certificate to be handed to the member who was originally submitted to the BMT. Recognition and measurement of expenses incurred on rahn tasjily financing transactions. Based on interviews with $\mathrm{Mr}$ Junaidi Nur (Head of Branch) dated February 28 at 13.38 WIB, states:

"Even in the BMT here (UGT Sidogiri branch of Malang city) the need for a map to store securities and documentary contracts that bear on this party (BMT) if deductible is Rp.10.000,00 (ten thousand rupiah), the cost goes into operational costs and we admit it as a cost when we get out ".

From the explanation, the BMT recognizes the costs associated with the need for the maintenance of land certificates are recognized at the time as BMT's operating costs in the office supplies are substantially expensed. With the following journal:

Journal of fees on rahn tasjily:

Dr. Operating costs (Office supplies) Rp. 10.000,00

Cr. Cash Rp. 10.000,00

Whereas in the presentation of rahn tasjily financing at BMT UGT Sidogiri, at the time of disbursement it is presented in the balance sheet on the assets side with the loan account of the service contract and disclosed in the balance sheet explanation. When receiving an installment of BMT, it covers the loan principal as a deduction from service contract loans that are presented on the asset side of the balance sheet and are disclosed in the balance sheet explanation.

Then ujrah income is presented at the amount received separately in the calculation of business results on the operating income side with the income account ujrah service agreement and disclosed in profit and loss. When issuing costs for rahn tasjily financing folders and documents, it is presented in the calculation of operating results in terms of operating and business costs with accounts of separate office equipment with income from service agreements, because income ujrah of service contracts is gross (not deducted 
Suhadak

from these costs) and disclosed in the explanation of profit and loss (Office Equipment).

On the side of the validity of the rahn tasjily financing contract at BMT UGT Sidogiri Malang city, which is based on the results of direct supervision to the branch that is carried out regularly in terms of compliance with sharia principles of financing products, especially the rahn tasjily financing products at BMT UGT Sidogiri Malang branch has complied with $100 \%$ (one hundred percent) according to sharia principles, the compliance information was obtained from the report of the 2015 BMG UGT Sidogiri and those acting as sharia supervisors were KH. A. Fuad Noer Hasan.

The results of the 2015 report of the Sidogiri BMT UGT BMT regarding the validity of the contract are supported by the results of interviews with Mr. Junaidi Nur (Branch Manager) dated February 28, 2017 at 09.55 WIB, stating:

"Rahn tasjily financing is financing where members pawn immovable property to obtain a loan, but members only submit securities (Property Ownership Proof), such as land certificates, house certificates, etc.".

And based on the results of interviews with Mr. Junaidi Nur (Branch Manager) dated February 28, 2017 at 10:15 WIB, stated:

"Based on the book i'anatuth tholibin, there are 3 (three) cases in the loan: first, if the loan provides benefits to the lender, then the contract is broken. Second, if the loan provides benefits to the borrower, the contract is damaged, and third, if the loan is guaranteed, then that is the right one. The guarantee that BMT will become the basis of the ujrah and the ujrah stipulated and requested for safekeeping of securities by BMT must not be submitted based on the financing ceiling at the time of the contract ".

And based on the results of interviews with Mr. Junaidi Nur as Head of Branch BMT UGT Sidogiri branch Malang city On February 28, 2017 at 09.55 WIB, stated as follows:

"In the rahn tasjily financing at the Malang branch of the UGT BMT there are several contracts that become the basis, namely the qardh contract when we give loans, rahn tasjily as a basis for holding securities and the ljarah contract as the basis for ujrah on guard". 
Based on the results of the supervision and interviews above, it can be concluded as follows: 1) Members only submit securities for assets owned by BMT UGT Sidogiri Malang city branches, and property remains in the control of members. 2) The cost of safeguards charged to members or income to be recognized by BMT UGT BMT UGT Sidogiri Malang is not delivered based on the ceiling, but directly asks directly with the nominal amount, 3) The contract used for safekeeping is based on ijarah agreement, and 4) Guarantee that the securities form does not transfer ownership of goods to BMT.

Analysis of the accounting treatment of rahn tasjily financing at BMT UGT Sidogiri Malang city branch with PAPSI part VII Qardh Loan Agreement. The guideline is the basis of the accounting treatment that specifically regulates the qardh contract, because rahn tasjily financing basically has a basic contract, namely qardh and PSAK 107 which is based on the ijarah agreement on rahn tasjily financing as in the following table, namely:

Table 1. Suitability of Accounting Treatment for Rahn tasjily Financing at BMT UGT Sidogiri Malang with Accounting Standards that Refer to Commonly Accepted Habits

\begin{tabular}{lll}
\hline \multicolumn{1}{c}{ Information } & \multicolumn{1}{c}{ BMT Accounting Treatment } & Suitability Level \\
\hline $\begin{array}{l}\text { Recognition and Measurement: } \\
\text { Rental income during the }\end{array}$ & $\begin{array}{l}\text { Ujrah } \text { income (rental income) is } \\
\text { recognized after the securing of }\end{array}$ & \\
$\begin{array}{l}\text { period of recognition is } \\
\text { recognized when the asset }\end{array}$ & Securities has been made & Suitability \\
has been transferred to the & & \\
tenant (SFAS 107) & & \\
\hline
\end{tabular}

Table 2. Level of Suitability of Accounting Treatment for Rahn tasjily at the BMT UGT in Sidogiri Malang with Accounting Standards that Refers to Commonly Accepted Habits (continued)

\begin{tabular}{llc}
\hline \multicolumn{1}{c}{ Information } & \multicolumn{1}{c}{ BMT Accounting Treatment } & Suitability Level \\
\hline $\begin{array}{l}\text { Recognition of repair costs } \\
\text { (costs of safeguards) not }\end{array}$ & $\begin{array}{l}\text { The cost of safekeeping is } \\
\text { recognized when the cost is } \\
\text { routine for ljarah objects are }\end{array}$ & incurred (incurred) \\
$\begin{array}{l}\text { recognized when they occur } \\
\text { (PSAK 107) }\end{array}$ & & Suitability \\
\end{tabular}


Suhadak

Qardh loans are recognized at the amount lent at the time of occurrence (PAPSI)

Treatment:

JIAFR | 134 on a net basis after deducting the related expenses, for example depreciation expense, maintenance and repairs expenses, etc. (PSAK 107 Par 31)

Qardh loans given to third parties are presented at the Qardh loan post (PAPSI part VII)

Disclosure:

The owner discloses in the financial statements related to the ljarah and ljarah muntahiyah bittamlik transactions, but is not limited to: (a) a general explanation of the contents of the contract that are significant ... (PSAK 107) Details of the number of Qardh loans based on funding sources, types use and economic sector. Loans to members are presented on the service loan postage

Ujrah's income is presented gross and separately with the cost of safekeeping requirements that are included in the operational cost post

Not Suitability

Suitability

Reveal the origin of ujrah income and details of costs in operational costs

Not Suitability

Disclose an explanation of service contract loans

Not Suitability

Amount of Qardh loans given to related parties (PAPSI part VII)

While the suitability analysis of the rahn tasjily financing contract at BMT UGT Sidogiri Malang city branch based on the Fatwa DSN MUI has shown similarities, including: 1 ) the collateral requested is securities (land certificate, etc.), 2) the cost of safekeeping ( place rent) is not related to the number of loans delivered at the time the contract takes place by conveying the nominal 
nominal amount to be paid by the member, 3) the use of ujrah is based on the ijarah contract, and 4) the guarantee of the form of securities does not transfer ownership of goods to BMT. The statement is in accordance with the results of interviews with Mr. Junaidi Nur (Branch Manager) on February 28 at 13.43 WIB, stating that:

"In the event of not being able to pay by members, we use a family system, asked how good it is from this financing, what is the item sold for. If the member is willing, he can sell himself or we help sell ......"

Therefore, in terms of the financing practice of rahn tasjily at BMT UGT Sidogiri which has been overseen by an internal sharia supervisor who is in charge of monitoring compliance with sharia principles of each product offered and seen from practice in accordance with Fatwa DSN MUI No.68/DSN -MUI/III/2008 about rahn tasjily.

\section{Conclusion}

Based on the results of research and discussion that has been described, then this article can be concluded, among others: 1) accounting treatment of rahn tasjily financing at BMT UGT Sidogiri Malang city branch based on PAPSI part VII about qardh loan agreement and PSAK 107 concerning ijarah accounting, including the following description this: Recognition and measurement of rahn tasjily financing for each transaction carried out, namely: 1) At the time of loan disbursement to members, the recognition is in accordance with PAPSI section VII qardh loan agreement point D.1 number 2 which states, qardh loans are recognized amount of the amount loaned at the time of occurrence. 2) Recognition of ujrah income (rental income) when the benefits of guarding services have been given, it is in accordance with PSAK 107 concerning ijarah accounting paragraph 14 which states, rental income during the contract period is recognized when the benefit of the asset has been handed over to the lessee. 3) When issuing the need for safeguards (costs), recognizing when the need is issued/when it occurs, it is in accordance with PSAK 107 concerning ijarah accounting paragraph 16a which states that the recognition of repair costs (maintenance costs) is not routine in the ijarah object recognized in when it occurs. rahn tasjily's 
Suhadak

financing presentation has not shown conformity with PSAK 107 in presenting ijarah revenue, and is in accordance with PAPSI section VII in presenting basic contract-based loans, namely qardh. However, in disclosure there is no conformity with PSAK 107 and PAPSI part VII of the ijarah contract and qardh contract.

The suitability of the rahn tasjily financing transaction at BMT UGT Sidogiri Malang branch city with the Fatwa DSN MUI No. 68/DSNMUI/III/2008 is in accordance with the criteria of practice carried out by BMT, including: 1) Guarantees in the form of securities (land certificate, etc.), 2) The amount of safeguards (rent of premises) is not associated with the number of loans delivered at the time the contract takes place by conveying the nominal amount of the ujrah to be paid by the member, and 3) the basis for taking ujrah based on the ijarah agreement. 4) guarantee that the securities form does not transfer ownership of goods to BMT.

\section{References}

Al-Quran

Ali, Z. (2008). Hukum Gadai Syariah. Jakarta: Sinar Grafika.

Antonio, M. S. (2007). Bank Syariah: Dari Teori ke Praktek. Jakarta: Gema Insani.

Bakhri, M. S. (2016). Aset BMT UGT Tembus Rp 2,2 Triliun. http://www.bmtugtsidogiri.co.id/berita-444.html. Diakses pada tanggal 6 januari 2016 pukul 19.30 WIB.

Bank Indonesia. (2013). Pedoman Akuntansi Perbankan Syariah Indonesia Tahun 2013.

DSN-MUI. (2014). Himpunan Fatwa Keuangan Syariah. Jakarta: ERLANGGA.

Emzir. (2010). Metode Penelitian Kualitatif: Analisis Data. Jakarta: PT. Rajagrafindo Persada.

IAI. (2009). E-book PSAK 107 tentang Akuntansi Ijarah.

Mardani. (2012). Fiqh Ekonomi Syariah: Fiqh Muamalah. Jakarta: Kencana.

Mardiasmo. (2004). Otonomi dan Manajemen Keuangan Daerah. Edisi Kedua. Yogyakarta: Penerbit Andi. 
Moleong, L. J. (2014). Metode Penelitian Kualitatif. Bandung: PT. Remaja Rosdakarya.

Mulawarman, A. D. (2009). Akuntansi Syariah: Teori, Konsep dan Laporan Keuangan. Jakarta: E Publishing Company.

Nawawi, I. (2012). Fikih Muamalah: Klasik dan Kontemporer. Bogor: Ghalia Indonesia.

RAT BMT UGT Sidogiri. (2015). Rapat Anggota Tahunan BMT UGT Sidogiri tahun buku 2015.

Rianto, M. A. (2010). Dasar-Dasar Pemasaran Bank Syariah. Bandung: CV Alfabeta.

Ridwan, M. (2004). Manajemen Baitul Mal wa Tamwil (BMT). Yogyakarta: UII Press.

Sahrani, Sohari \& Abdullah, R. 2011. Fikih Muamalah. Bogor: Ghalia Indonesia.

Sudarsono, H. (2007). Bank \& Lembaga Keuangan Syari'ah. Yogyakarta: EKONESIA.

Suhendi, H. (2010a). Fiqh Muamalah. Jakarta: Raja Grafindo Persada.

Suhendi, H. (2013b). Fiqh Muamalah. Jakarta: Raja Grafindo Persada.

Sumiyanto, A. (2008). BMT Menuju Koperasi Moders. Yogyakarta: PT ISES Consulting Indonesia.

Sutedi, A. (2011). Hukum Gadai Syariah. Bandung: Alfabeta.

Syafi'i, R. (2001). Fiqh Muamalah. Bandung: CV Pustaka Setia.

Triyuwono, I. (2000a). Organisasi dan Akuntansi Syariah. Yogyakarta: LkiS

Triyuwono, I. (2006b). Perspektif, Metodologi dan Teori Akuntansi Syariah. Jakarta: PT. Rajagrafindo Persada.

Undang-Undang No. 10 Tahun 1998 tetang Perbankan.

Wangsawidjaja. (2012). Pembiayaan Bank Syariah. Jakarta: PT Gramedia Pustaka Utama. 
JIAFR | 138 